Alison Klein, Anglophone Literature of Caribbean Indenture: The Seductive Hierarchies of Empire. Cham, Switzerland: Palgrave Macmillan, 2018. vii $+25^{8}$ pp. (Cloth US\$84.99)

In 1838, the first shipload of indentured servants from India arrived in British Guiana to replace the loss of African slave labor. After some early interruptions, this contract labor system became the basis upon which the postemancipation Caribbean plantation society functioned. Between 1838 and 1917, an estimated 500,000 indentured servants were transported by Western European powers mainly to British Guiana, Trinidad, Suriname, and the Lesser Antilles. An estimated 150,000 Indians returned to India when their contracts expired while 350,000 settled in the Caribbean in exchange for their return passage. At the same time, thousands of Chinese contract laborers arrived in Cuba and the British Caribbean. The story of indentured servitude in the region has received enormous attention and is no longer an appendage to Caribbean literature. In what way, then, does Anglophone Literature of Caribbean Indenture contribute to the indentured narrative? Alison Klein uses novels, autobiographies, interviews, and poems to address "the intimate relationships, often sexual in nature, between the colonizers and colonized, and between colonized citizens" (p. 3), focusing on the hierarchical ideologies of gender, ethnicity, and class that developed during the period of indentured imperialism.

Following the introduction, Chapter 2 uses the nonfiction autobiographies of indentured Indians Munshi Rahman Khan and Alice Persaud to reveal the colonial legislative prejudices toward marriage customs in the laboring population. Marriage norms revolved around the Victorian model of civilization and progress which was incompatible with the laborers' culture. However, the laboring population was not free from internal social dissonance. Klein argues that women were caught in the European and Indian indentured world of patriarchy. Women's resistance was not transformative. Subsequently, colonial legislation around marriage bound women into "constricting gendered, classed and racialized roles" (p. 55).

Chapter 3 assesses the only two novels written during the period of Indian indenture, Edward Jenkins's Lutchmee and Dilloo (1877) and A.R.F. Webber's Those that be in Bondage (1917); Jenkins was British and Webber was Guyanese of European and African heritage. Klein argues that these authors revealed the abuses of indenture but rarely deviated from upholding the status quo of the plantation hierarchy of race, class, and gender. They depicted the Indian characters as villains and victims and the European characters as victorious. The "idealization of empire" (p. 8o) permeated the novels, motivating Klein to 
declare that the authors were trying to promote the colonial rhetoric of the indenture system.

Chapter 4 analyzes the characters in three novels-David Dabydeen's The Counting House (2005), Sharlow Mohammed's The Promise (1995), and Patricia Powell's The Pagoda (1998) — about the exploitative relationship between Indian women and British men, showing that women were encouraged to use their traditional customs of domesticity to deal with their abusive relationship. Women were viewed as representative of Indian culture, which had to be controlled and protected, reinforcing their double marginalization.

Chapter 5 dissects the poetry of Rajkumar Singh, Mahadia Das, Dabydeen, Lelawattee Manoo-Rahming, and Easton Lee to show the connection of the female indentured body to the fertility of the land. Although diverse in tone and temperament, they all encourage support and solidarity for the anticolonial/independence movement sweeping across the Caribbean beginning in the 1960s. They urge the descendants of female indentured servants to devote themselves to the birthing and building of new nations. Nevertheless, Klein argues that although "parallels [were] drawn between the woman's body and the land [they] tend to repeat colonial tropes" (p. 177).

Chapter 6 examines Peggy Mohan's Jahajin (2007) and Cristina Garcia's Monkey Hunting (2003), which deal with indentured nostalgia, using the indentured experience as a platform to move forward rather than being trapped by the past. Klein understands that although this approach might not solve the indignity of indenture, it is promising by "exploring the past to better understand the present" and may hold the key to breaking oppressive cycles in the future (p. 220).

Klein connects these chapters through the narration of brutality as well as the resistance and escape from indenture. However, she is convincing that the autobiographies, novels, and poems, whether historical or contemporary, have reproduced the hierarchical ideologies of race, class, and gender of indentured imperialism. This is a remarkable literary feat that makes an important contribution to the study of literature dealing with Asian Caribbean indenture. The narrative of reproducing colonial tropes in an attempt to right a historical wrong will certainly be useful to students, professors, and researchers since it holds a strong potential to instigate and inspire debate.

\section{Lomarsh Roopnarine}

Department of History and Philosophy, Jackson State University, Jackson MS, USA

lomarsh.roopnarine@jsums.edu 